\title{
The Effect of High Co Addition on the Properties of $\mathrm{Fe}_{79} \mathrm{Zr}_{9} \mathrm{~B}_{12}$ and $\mathrm{Fe}_{76} \mathrm{Zr}_{9} \mathrm{~B}_{15}$ Alloys
}

\author{
W.Q. Yu, D. Long, Y.D. LiU, Y.M. Sun And Z. HuA* \\ Key Laboratory of Functional Materials Physics and Chemistry of the Ministry of Education, \\ Jilin Normal University, Siping 136000, Jilin, P.R. China
}

(Received February 4, 2015; revised version August 14, 2015; in final form September 22, 2015)

Thermal properties, microstructure and magnetic properties of $\mathrm{Fe}_{79} \mathrm{Zr}_{9} \mathrm{~B}_{12}, \mathrm{Fe}_{76} \mathrm{Zr}_{9} \mathrm{~B}_{15}, \mathrm{Fe}_{39.5} \mathrm{Co}_{39.5} \mathrm{Zr}_{9} \mathrm{~B}_{12}$ and $\mathrm{Fe}_{38} \mathrm{Co}_{38} \mathrm{Zr}_{9} \mathrm{~B}_{15}$ alloys were investigated by differential thermal analysis, $\mathrm{X}$-ray diffraction and vibrating sample magnetometer. High Co addition has a significant impact on the properties of alloys. High Co addition increases the main crystallization peak temperature and the crystallization activation energy. Moreover, high Co addition changes the crystallization products and influences the crystallization processes of $\mathrm{Fe}_{79} \mathrm{Zr}_{9} \mathrm{~B}_{12}$ and $\mathrm{Fe}_{76} \mathrm{Zr}_{9} \mathrm{~B}_{15}$ alloys. The specific saturation magnetization $\left(\boldsymbol{M}_{\mathrm{s}}\right)$ increases and coercivity $\left(\boldsymbol{H}_{\mathrm{c}}\right)$ decreases by high Co additions.

DOI: $10.12693 /$ APhysPolA.128.340

PACS: 65.60.+a, 61.43.Dq

\section{Introduction}

Fe-based amorphous and nanocrystalline alloys have been extensively investigated because of their excellent soft magnetic properties [1-6]. The magnetic properties strongly depend on the crystallization products. The study on the crystallization process of Fe-based amorphous alloy is very important. Besides $\alpha$-Fe phase, the $\alpha$-Mn type [7-11] and $\mathrm{Fe}_{23} \mathrm{~B}_{6}[7,12]$ metastable phases were observed in the initial crystallization processes of Fe-based amorphous alloys. The $\alpha$-Mn type phase has bcc structure and transforms to $\alpha$-Fe phase during crystallization $[7,13]$. The $\mathrm{Fe}_{23} \mathrm{~B}_{6}$ phase adopts the $\mathrm{Cr}_{23} \mathrm{C}_{6}$ prototype structure and decomposes into $\alpha$ $\mathrm{Fe}, \mathrm{Fe}_{3} \mathrm{~B}$ and $\mathrm{Fe}_{2} \mathrm{~B}$ phases during crystallization [7].

Fe-based amorphous phase exhibits very low Curie temperature. To meet the demand for soft magnetic materials for high frequency and high temperature applications, Hitperm alloy is developed [14]. Since then, extensive research has been carried out on Hitperm type $\mathrm{Fe}(\mathrm{Co})-\mathrm{M}-\mathrm{B}(\mathrm{Cu})$ alloys $(\mathrm{M}=\mathrm{Zr}, \mathrm{Hf}, \mathrm{Nb}$ etc.). Majumdar et al. studied the $\mathrm{Fe}(\mathrm{Co})-\mathrm{Zr}-\mathrm{B}-\mathrm{Cu}$ alloys and found that coercivity, saturation magnetization and Curie temperature all increased due to the addition of Co [15].

Ping et al. found that FeCo nanocrystalline grains nucleated in the amorphous precursor of HITPERM alloy without the need for $\mathrm{Cu}$ as a nucleation agent [16]. Ohnuma et al. found that the addition of Co to Fe-based amorphous alloys influenced the crystallization process significantly [17]. Willard et al. studied the crystallization behavior of $\mathrm{Fe}_{44} \mathrm{Co}_{44} \mathrm{Zr}_{7} \mathrm{~B}_{4} \mathrm{Cu}_{1}$ alloy and reported that the crystallites were ordered $\alpha$ $\mathrm{Fe}(\mathrm{Co})$ phase (B2 structure) [14]. Long et al. studied the $\mathrm{Fe}_{40} \mathrm{Co}_{40} \mathrm{Nb}_{4} \mathrm{~B}_{13} \mathrm{Ge}_{2} \mathrm{Cu}_{1}$ alloy and reported that

*corresponding author; e-mail: huazhong196110@163.com the $\mathrm{Fe}_{23} \mathrm{~B}_{6}$-type phase $(\mathrm{FeCoNb})_{23} \mathrm{~B}_{6}$ was the secondary crystallization product [18].

In this paper, the $\alpha$-Mn type and $\mathrm{Fe}_{23} \mathrm{~B}_{6}$ metastable phases are observed in the crystallization processes of $\mathrm{Fe}_{79} \mathrm{Zr}_{9} \mathrm{~B}_{12}$ and $\mathrm{Fe}_{76} \mathrm{Zr}_{9} \mathrm{~B}_{15}$ alloys. Co additions affect the crystallization processes and the corresponding magnetic properties. The effect of high Co addition on the thermal stability, crystallization process and magnetic properties of $\mathrm{Fe}_{79} \mathrm{Zr}_{9} \mathrm{~B}_{12}$ and $\mathrm{Fe}_{76} \mathrm{Zr}_{9} \mathrm{~B}_{15}$ alloys is studied.

\section{Experimental details}

$\mathrm{Fe}_{79} \mathrm{Zr}_{9} \mathrm{~B}_{12}, \quad \mathrm{Fe}_{76} \mathrm{Zr}_{9} \mathrm{~B}_{15}, \quad \mathrm{Fe}_{39.5} \mathrm{Co}_{39.5} \mathrm{Zr}_{9} \mathrm{~B}_{12}$ and $\mathrm{Fe}_{38} \mathrm{Co}_{38} \mathrm{Zr}_{9} \mathrm{~B}_{15}$ amorphous alloys were prepared by melt-spinning. The four kinds of amorphous alloys were all annealed at 573, 823, 873, 923 and $973 \mathrm{~K}$ for $1 \mathrm{~h}$. The thermal properties were investigated by differential thermal analysis (DTA, TG/DTA-6300). The microstructure was examined by X-ray diffraction (XRD, $\left.\mathrm{D} / \max 2500 / \mathrm{PC}, \mathrm{Cu} K_{\alpha_{1}}, \lambda=1.5406 \AA\right)$. Magnetic characteristics were measured with the use of vibrating sample magnetometer (VSM, Lake Shore M7407).

\section{Results and discussion}

Figure 1 shows the DTA traces of the asquenched $\mathrm{Fe}_{79} \mathrm{Zr}_{9} \mathrm{~B}_{12}, \quad \mathrm{Fe}_{76} \mathrm{Zr}_{9} \mathrm{~B}_{15}, \mathrm{Fe}_{39.5} \mathrm{Co}_{39.5} \mathrm{Zr}_{9} \mathrm{~B}_{12}$ and $\mathrm{Fe}_{38} \mathrm{Co}_{38} \mathrm{Zr}_{9} \mathrm{~B}_{15}$ alloys at three different heating rates of 10,30 , and $50 \mathrm{~K} / \mathrm{min}$. Co addition induces a low exothermic peak, which precedes the main crystallization peak. It is supposed to be a pre-crystallization effect $[19,20]$. At the same time, high Co addition decreases the crystallization temperature zone between the first crystallization peak (the main crystallization peak) and the second crystallization peak.

The Kissinger plots for the main crystallization peak $T_{\mathrm{p}}$ are shown in Fig. 2. The crystallization activation energies $E$ for $T_{\mathrm{p}}$ are calculated using the Kissinger 

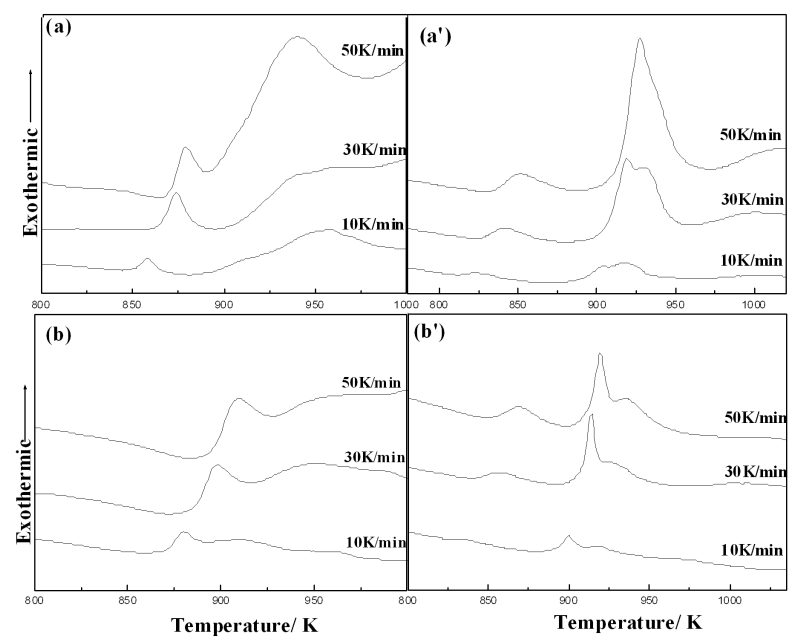

Fig. 1. DTA traces of the as-quenched $\mathrm{Fe}_{79} \mathrm{Zr}_{9} \mathrm{~B}_{12}$ (a), $\mathrm{Fe}_{76} \mathrm{Zr}_{9} \mathrm{~B}_{15} \quad$ (b), $\quad \mathrm{Fe}_{39.5} \mathrm{Co}_{39.5} \mathrm{Zr}_{9} \mathrm{~B}_{12} \quad(\mathrm{a} /)$ and $\mathrm{Fe}_{38} \mathrm{Co}_{38} \mathrm{Zr}_{9} \mathrm{~B}_{15}(\mathrm{~b} /$ ) alloys at three different heating rates of 10,30 and $50 \mathrm{~K} / \mathrm{min}$.

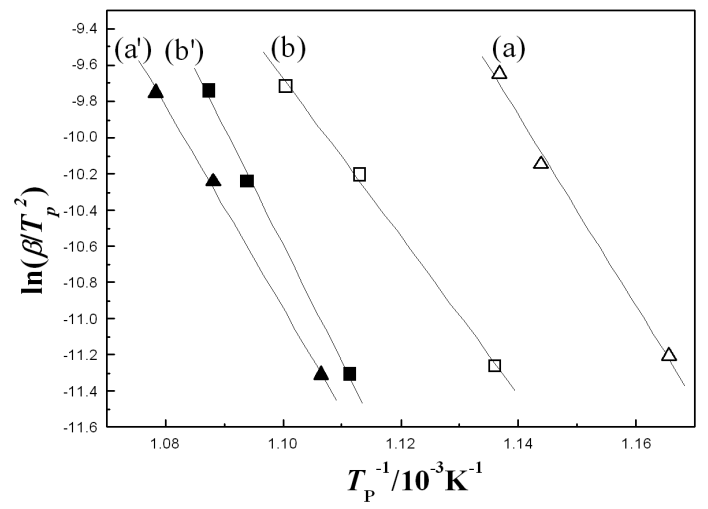

Fig. 2. Kissinger plots of $\mathrm{Fe}_{79} \mathrm{Zr}_{9} \mathrm{~B}_{12}$ (a), $\mathrm{Fe}_{76} \mathrm{Zr}_{9} \mathrm{~B}_{15} \quad(b), \quad \mathrm{Fe}_{39.5} \mathrm{Co}_{39.5} \mathrm{Zr}_{9} \mathrm{~B}_{12} \quad\left(a^{\prime}\right)$ and $\mathrm{Fe}_{38} \mathrm{Co}_{38} \mathrm{Zr}_{9} \mathrm{~B}_{15}\left(b^{\prime}\right)$ alloys for $T_{\mathrm{p}}$.

equation [21] by plotting $\ln \left(\beta / T^{2}\right)$ versus $1 / T$ (a straight line with the slope of $E / R$ can be obtained), where $R$ is the gas constant, $\beta$ is the heating rate $(\mathrm{K} / \mathrm{min})$ and $T$ is a specific absolute temperature.

TABLE I

The main crystallization peaks $T_{\mathrm{p}}$ at a heating rate of $10 \mathrm{~K} / \mathrm{min}$ and the crystallization activation energies of as-quenched $\mathrm{Fe}_{79} \mathrm{Zr}_{9} \mathrm{~B}_{12}, \mathrm{Fe}_{76} \mathrm{Zr}_{9} \mathrm{~B}_{15}$, $\mathrm{Fe}_{39.5} \mathrm{Co}_{39.5} \mathrm{Zr}_{9} \mathrm{~B}_{12}$ and $\mathrm{Fe}_{38} \mathrm{Co}_{38} \mathrm{Zr}_{9} \mathrm{~B}_{15}$ alloys.

\begin{tabular}{c|c|c}
\hline \hline Compositions [at.\%] & $T_{\mathrm{p}}[\mathrm{K}]$ & $E_{\mathrm{p}}[\mathrm{KJ} / \mathrm{mol}]$ \\
\hline $\mathrm{Fe}_{79} \mathrm{Zr}_{9} \mathrm{~B}_{12}$ & 857.4 & 440.3 \\
$\mathrm{Fe}_{39.5} \mathrm{Co}_{39.5} \mathrm{Zr}_{9} \mathrm{~B}_{12}$ & 904.7 & 463.3 \\
$\mathrm{Fe}_{76} \mathrm{Zr}_{9} \mathrm{~B}_{15}$ & 879.9 & 363.5 \\
$\mathrm{Fe}_{38} \mathrm{Co}_{38} \mathrm{Zr}_{9} \mathrm{~B}_{15}$ & 900.1 & 536.4
\end{tabular}

The main crystallization peaks $T_{\mathrm{p}}$ and crystallization activation energies $E$ of the as-quenched alloys are listed in Table I. High Co addition increases the main crystallization peak temperature and the crystallization activation energy. That is to say, high Co addition increases the thermal stability.

XRD patterns of $\mathrm{Fe}_{79} \mathrm{Zr}_{9} \mathrm{~B}_{12}$ (a), $\mathrm{Fe}_{76} \mathrm{Zr}_{9} \mathrm{~B}_{15}$ (b), $\mathrm{Fe}_{39.5} \mathrm{Co}_{39.5} \mathrm{Zr}_{9} \mathrm{~B}_{12}\left(\mathrm{a}^{\prime}\right)$, and $\mathrm{Fe}_{38} \mathrm{Co}_{38} \mathrm{Zr}_{9} \mathrm{~B}_{15}\left(\mathrm{~b}^{\prime}\right)$ alloys corresponding to different annealing temperatures are shown in Fig. 3. No crystalline peaks are observed in the as-quenched alloys, which indicates that the as-quenched alloys are all amorphous. The effects of crystallization

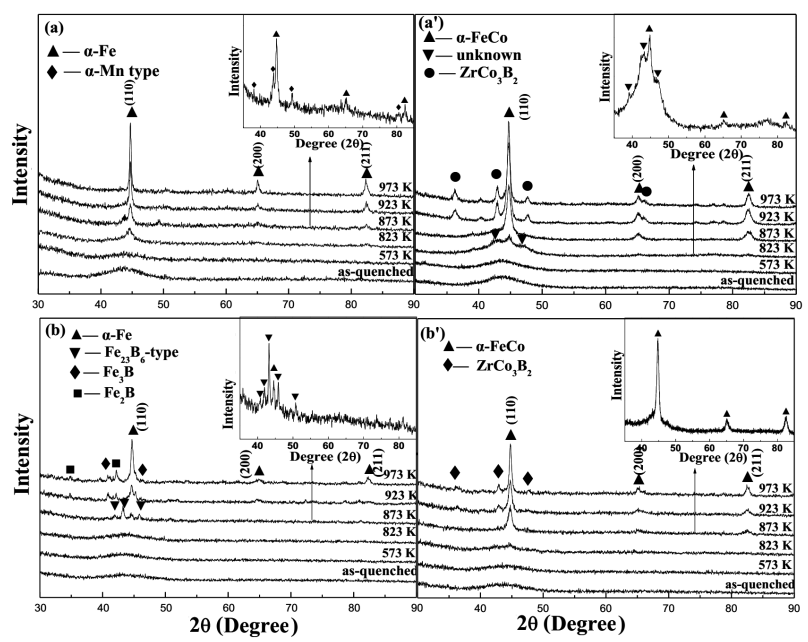

Fig. 3. XRD patterns of $\mathrm{Fe}_{79} \mathrm{Zr}_{9} \mathrm{~B}_{12}$ (a), $\mathrm{Fe}_{76} \mathrm{Zr}_{9} \mathrm{~B}_{15} \quad$ (b), $\quad \mathrm{Fe}_{39.5} \mathrm{Co}_{39.5} \mathrm{Zr}_{9} \mathrm{~B}_{12} \quad$ (a') and $\mathrm{Fe}_{38} \mathrm{Co}_{38} \mathrm{Zr}_{9} \mathrm{~B}_{15}$ (b') alloys as-quenched and annealed at different annealing temperatures. The insets correspond to the magnified XRD, respectively.

TABLE II

Crystallization processes of $\mathrm{Fe}_{79} \mathrm{Zr}_{9} \mathrm{~B}_{12}, \mathrm{Fe}_{76} \mathrm{Zr}_{9} \mathrm{~B}_{15}$, $\mathrm{Fe}_{39.5} \mathrm{Co}_{39.5} \mathrm{Zr}_{9} \mathrm{~B}_{12}$ and $\mathrm{Fe}_{38} \mathrm{Co}_{38} \mathrm{Zr}_{9} \mathrm{~B}_{15}$ alloys.

\begin{tabular}{c|c}
\hline \hline Compositions [at.\%] & Crystallization process \\
\hline $\mathrm{Fe}_{79} \mathrm{Zr}_{9} \mathrm{~B}_{12}$ & amorphous $\rightarrow$ residual amorphous \\
& $+\alpha$-Fe $+\alpha$-Mn type $\rightarrow \alpha$-Fe \\
$\mathrm{Fe}_{39.5} \mathrm{Co}_{39.5} \mathrm{Zr}_{9} \mathrm{~B}_{12}$ & $\begin{array}{c}\text { amorphous } \rightarrow \text { residual amorphous }+\alpha \text {-FeCo } \\
+ \text { unknown phase } \rightarrow \alpha \text {-FeCo }+\mathrm{ZrCo} \mathrm{B}_{2}\end{array}$ \\
$\mathrm{Fe}_{76} \mathrm{Zr}_{9} \mathrm{~B}_{15}$ & amorphous $\rightarrow$ residual amorphous \\
& $+\alpha-\mathrm{Fe}+\mathrm{Fe}_{23} \mathrm{~B}_{6}$ type $\rightarrow \alpha$-Fe $+\mathrm{Fe}_{3} \mathrm{~B}+\mathrm{Fe}_{2} \mathrm{~B}$ \\
$\mathrm{Fe}_{38} \mathrm{Co}_{38} \mathrm{Zr}_{9} \mathrm{~B}_{15}$ & amorphous $\rightarrow$ residual amorphous \\
& $+\alpha$-FeCo $\rightarrow \alpha-\mathrm{FeCo}+\mathrm{ZrCo}_{3} \mathrm{~B}_{2}$
\end{tabular}

processes of four kinds of alloys are described in Table II. High Co addition influences obviously the crystallization processes of alloys. The $\alpha$-Mn type and $\mathrm{Fe}_{23} \mathrm{~B}_{6}$ type metastable phases are observed in the initial crystallization processes of $\mathrm{Fe}_{79} \mathrm{Zr}_{9} \mathrm{~B}_{12}$ and $\mathrm{Fe}_{76} \mathrm{Zr}_{9} \mathrm{~B}_{15}$ alloys, respectively. The unknown metastable phase is observed in the initial crystallization process of $\mathrm{Fe}_{39.5} \mathrm{Co}_{39.5} \mathrm{Zr}_{9} \mathrm{~B}_{12}$ alloy. No metastable phase and only $\alpha$-FeCo phase is observed in the crystallization process of $\mathrm{Fe}_{38} \mathrm{Co}_{38} \mathrm{Zr}_{9} \mathrm{~B}_{15}$ alloy.

Specific saturation magnetization $\left(\boldsymbol{M}_{\mathrm{s}}\right)$ and coercivity $\left(\boldsymbol{H}_{\mathrm{c}}\right)$ of four kinds of alloys as a function of annealing temperature $\left(T_{\mathrm{a}}\right)$ are shown in Fig. 4. $\boldsymbol{M}_{\mathrm{s}}$ of 
four kinds of alloys increases with increase of annealing temperature. On the whole, $\boldsymbol{M}_{\mathrm{S}}$ of Co-containing alloys are larger than that of Co-free alloys. For $\mathrm{Fe}_{79} \mathrm{Zr}_{9} \mathrm{~B}_{12}$ alloy, high Co addition leads to the reduction of $\boldsymbol{H}_{\mathrm{c}}$ to a great extent. An abruptly deterioration $\left(\boldsymbol{H}_{\mathrm{c}}\right)$ is observed in the $\mathrm{Fe}_{79} \mathrm{Zr}_{9} \mathrm{~B}_{12}$ alloy at $873 \mathrm{~K}$, which is related to the precipitation of $\alpha$-Mn type phase [8]. The observed magnetic softening phenomenon later is due to the disappearance of $\alpha$-Mn type phase and the stronger exchange coupling between $\alpha$-Fe nanocrystals. For $\mathrm{Fe}_{76} \mathrm{Zr}_{9} \mathrm{~B}_{15}$ alloy, high Co addition leads to the decrease of $\boldsymbol{H}_{\mathrm{c}}$ at high temperature. $\boldsymbol{H}_{\mathrm{c}}$ of $\mathrm{Fe}_{76} \mathrm{Zr}_{9} \mathrm{~B}_{15}$ alloy increases continuously above $823 \mathrm{~K}$. There is no abrupt deterioration phenomenon at $873 \mathrm{~K}$. Hono [22] and Zhang [23] et al. suggested that the $\mathrm{Fe}_{23} \mathrm{~B}_{6}$ phase is a soft magnetic phase and its formation does not adversely affect the magnetic properties. $\boldsymbol{H}_{\mathrm{c}}$ of $\mathrm{Fe}_{38} \mathrm{Co}_{38} \mathrm{Zr}_{9} \mathrm{~B}_{15}$ alloy increases continuously above $873 \mathrm{~K}$ and is lower than that of $\mathrm{Fe}_{76} \mathrm{Zr}_{9} \mathrm{~B}_{15}$ alloy. In general, the soft magnetic properties of $\mathrm{Co}-$ containing alloys are better than those of Co-free alloys.
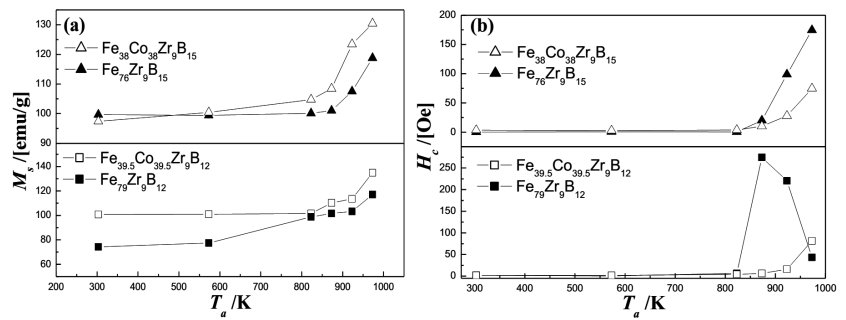

Fig. 4. Specific saturation magnetization $\left(\boldsymbol{M}_{\mathrm{S}}\right)$ and coercivity $\left(\boldsymbol{H}_{\mathrm{c}}\right)$ of $\mathrm{Fe}_{79} \mathrm{Zr}_{9} \mathrm{~B}_{12}, \quad \mathrm{Fe}_{76} \mathrm{Zr}_{9} \mathrm{~B}_{15}$, $\mathrm{Fe}_{39.5} \mathrm{Co}_{39.5} \mathrm{Zr}_{9} \mathrm{~B}_{12}$ and $\mathrm{Fe}_{38} \mathrm{Co}_{38} \mathrm{Zr}_{9} \mathrm{~B}_{15}$ alloys as a function of annealing temperature $\left(T_{\mathrm{a}}\right)$.

\section{Conclusions}

1. A pre-crystallization effect is found in the high $\mathrm{Co}-$ containing alloys and not found in the Co-free alloys. High Co additions also increase the thermal stability of alloys.

2. High Co additions influence the crystallization processes of alloys. The crystallization process of $\mathrm{Fe}_{79} \mathrm{Zr}_{9} \mathrm{~B}_{12}$ alloy runs as follows: amorphous $\rightarrow$ residual amorphous $+\alpha$-Fe $+\alpha$-Mn type $\rightarrow \alpha$-Fe. The crystallization process of $\mathrm{Fe}_{39.5} \mathrm{Co}_{39.5} \mathrm{Zr}_{9} \mathrm{~B}_{12}$ alloy has the following course: amorphous $\rightarrow$ residual amorphous $+\alpha$-FeCo + unknown phase $\rightarrow \alpha$ $\mathrm{FeCo}+\mathrm{ZrCo}_{3} \mathrm{~B}_{2}$. The crystallization process of $\mathrm{Fe}_{76} \mathrm{Zr}_{9} \mathrm{~B}_{15}$ alloy runs as follows: amorphous $\rightarrow$ residual amorphous $+\alpha$-Fe $+\mathrm{Fe}_{23} \mathrm{~B}_{6}$ type $\rightarrow \alpha$ $\mathrm{Fe}+\mathrm{Fe}_{3} \mathrm{~B}+\mathrm{Fe}_{2} \mathrm{~B}$. The crystallization process of $\mathrm{Fe}_{38} \mathrm{Co}_{38} \mathrm{Zr}_{9} \mathrm{~B}_{15}$ alloy has the following course: amorphous $\rightarrow$ residual amorphous $+\alpha$-FeCo $\rightarrow \alpha-$ $\mathrm{FeCo}+\mathrm{ZrCo}_{3} \mathrm{~B}_{2}$.

3. The soft magnetic properties of Co-containing alloys are better than those of Co-free alloys.

\section{Acknowledgments}

This work was funded by Science and Technology Studying Project of "12th five-year" Office of Education of Jilin Province (No. 2014-485 and No. 2015-228) and the National Natural Science Foundation of China (No. 51301075).

\section{References}

[1] L.T.M. Hoa, K. Ishizaki, D.M. Chien, Adv. Nat. Sci. Nanosci. Nanotechnol. 1, 015005 (2010).

[2] A. Fernández-Martínez, P. Gorría, G.J. Cuello, J.D. Santos, M.J. Pérez, J. Non-Cryst. Solids 353, 855 (2007).

[3] H. Huang, G. Shao, P. Tsakiropoulos, J. Alloys Comp. 459, 185 (2008).

[4] M. Al-Haj, J. Barry, J. Mater. Sci. Lett. 17, 1125 (1998).

[5] D.M. Zhu, K. Raviprasad, K. Suzuki, S.P. Ringer, Mater. Forum 27, 74 (2004).

[6] C.Q. Zhang, Z.H. Zhang, Z. Qi, Y.X. Qi, J.Y. Zhang X.F. Bian, J. Non-Cryst. Solids 354, 3812 (2008).

[7] M. Imafuku, S. Sato, H. Koshiba, E. Matsubara, A. Inoue, Scr. Mater. 44, 2369 (2001).

[8] W.Q. Yu, Y.M. Sun, Y.D. Liu, J. Liu, B. Zuo, L.H. Liu, L.R. Dong, Z. Hua, Optoelectron. Adv. Mater.-Rapid Commun. 6, 153 (2012).

[9] I.V. Lyasotskii, N.B. Dyakonova, E.N. Vlasova, D.L. Dyakonov, M.Yu. Yazvitskii, Physica Status Solidi A 203, 259 (2006).

[10] I.V. Lyasotsky, N.B. Dyakonova, D.L. Dyakonov, E.N. Vlasova, M.Yu. Jazvitsky, Rev. Adv. Mater. Sci. 18, 695 (2008).

[11] T. Nagase, Y. Umakoshi, ISIJ Int. 46, 1371 (2006).

[12] E.F. Kneller, IEEE Trans. Magn. 27, 3588 (1991).

[13] W.Q. Yu, Y.M. Sun, Z. Hua, Appl. Surf. Sci. 257, 9733 (2011).

[14] M.A. Willard, D.E. Laughlin, M.E. McHenry, D. Thoma, K. Sickafus, J.O. Cross, V.G. Harris, J. Appl. Phys. 84, 6773 (1998)

[15] B. Majumdar, S. Bysak, D. Akhtar, J. Magn. Magn. Mater. 309, 300 (2007).

[16] D.H. Ping, Y.Q. Wu, K. Hono, M.A. Willard, M.E. McHenry, D.E. Laughlin, Scr. Mater. 45, 781 (2001).

[17] M. Ohnuma, D.H. Ping, T. Abe, H. Onodera, K. Hono, Y. Yoshizawa, J. Appl. Phys. 93, 9186 (2003).

[18] J.G. Long, P.R. Ohodnicki, D.E. Laughlin, M.E. McHenry, J. Appl. Phys. 101, 09N114 (2007).

[19] E. Illeková, P. Švec, M. Miglierini, J. Non-Cryst. Solids 353, 3342 (2007).

[20] W.Q. Yu, Y.M. Sun, L.H. Liu, L.R. Dong, Z. Hua, Acta Phys. Pol. A 120, 1034 (2011).

[21] H.E. Kissinger, Anal. Chem. 29, 1702 (1957).

[22] K. Hono, D.H. Ping, Mater. Sci. Eng. A 304-306, 81 (2001).

[23] Y.R. Zhang, R.V. Ramanujan, J. Alloys Comp. 403 , 197 (2005). 